\title{
Nauplius
}

The Journal of The

Brazilian Crustacean Society

This article is part of the tribute offered

by the Brazilian Crustacean Society

in memoriam of Michael Türkay

outstanding contribution to Carcinology

e-ISSN 2358-2936

www.scielo.br/nau

www.crustacea.org.br

Original Article

\section{Description of the first juvenile stage of Dilocarcinus septemdentatus (Herbst, 1783) (Crustacea, Decapoda, Trichodactylidae)}

Cleverson Rannieri Meira dos Santos ${ }^{1}$ iD orcid.org/0000-0003-0467-2798

Rony Roberto Ramos Vieira ${ }^{2}$ (iD orcid.org/0000-0003-0368-5300

1 Museu Paraense Emílio Goeldi. Av. Perimetral, 1901, Terra Firme. 66077-830 Belém, Pará, Brazil.

CRMS E-mail: crsantos@museu-goeldi.br

2 Programa de Capacitação Institucional, Museu Paraense Emílio Goeldi, Coordenação de Zoologia. Av. Perimetral, 1901, Terra Firme. 66077-830 Belém, Pará, Brazil.

RRRV E-mail: ronycrab@gmail.com

ZOOBANK http://zoobank.org/urn:lsid:zoobank.org:pub:1BC84582-5A7C-44BD-

BB92-3CF64D451443

\section{Abstract}

A total of 38 freshwater brachyuran species occur in Brazil, of which 79\% are distributed in the northern region. However, for only two species of freshwater crabs are descriptions available for their juveniles. The importance of these studies lies in understanding of life-cycle aspects as well the potential elucidation of phylogenetic relationships within the group because the characters are usually solely based on adult specimens. The morphology of the first juvenile stage of the Dilocarcinus septemdentatus (Herbst, 1783) is described and illustrated for the first time based on specimens hatched by an ovigerous female collected in the northeastern region of the Brazilian

CORRESPONDING AUTHOR Cleverson Rannieri M. dos Santos crsantos@museu-goeldi.br

SUBMITTED 23 February 2017 ACCEPTED 09 September 2017 PUBLISHED 27 November 2017

Guest Editor

Célio Magalhães

DOI 10.1590/2358-2936e2017031
Amazon. Juveniles of Dilocarcinus pagei Stimpson, 1861 and D. septemdentatus have one flagellar segment on the exopod of the first maxilliped while the only described juvenile of an unidentified species of Trichodactylus Latreille, 1828 has two. Dilocarcinus septemdentatus differs from other congeneric species mainly in the number of setae on the antennae and number of segments of the mandibular palp. Variations in the number of segments and 
aesthetascs enable the comparison between the juveniles of D. septemdentatus with those of other Brachyuran species previously studied and suggest possible adaptations to freshwater environments.

\section{KEY WORDS}

Brachyura, juvenile development, aesthetascs, freshwater crab, morphology.

\section{INTRODUCTION}

Freshwater crabs are Brachyura Heterotremata that reproduce exclusively by direct development with the larval stages occurring inside the egg and newly hatched juveniles exhibiting characteristics similar to those of the adults (sensu Williamson, 1969; Cumberlidge and $\mathrm{Ng}, 2009$ ). This group includes more than 1,280 species in 220 genera in the Neotropical, Afrotropical, Palearctic, Oriental and Australasian regions (Cumberlidge and $\mathrm{Ng}, 2009$ ). A total of $43 \%$ of all Brazilian freshwater decapod fauna occur in the Amazon basin (Magalhães, 2003).

Sternberg et al. (1999) separated the freshwater crabs into two monophyletic groups, the first one with five families and the other one consisting of the family Trichodactylidae H. Milne-Edwards, 1853, but this classification is controversial. Bott (1970), Cumberlidge (1999) and Martin and Davis (2001) included the Trichodactylidae in the superfamily Portunoidea Rafinesque, 1815, but Števčić (2005) transferred it to the superfamily Trichodactyloidea $\mathrm{H}$. Milne-Edwards, 1853, which was followed by $\mathrm{Ng}$ et al. (2008), Cumberlidge and Ng (2009), and De Grave et al. (2009). The family has two subfamilies, Dilocarcininae Preztmann, 1978, consisting of 12 genera and 33 species, and Trichodactylinae H. Milne Edwards, 1853, encompassing 3 genera and 16 species (De Grave et al., 2009). In Brazil, Trichodactylidae is represented by 10 genera and 29 species that occur in all of the river basins in the country, excluding the temporary rivers of the semiarid northeastern region, but are primarily distributed in the Amazon basin (Magalhães, 2003). These animals are found in streams, lakes, wetlands, backwaters and swamps, where they occupy various microhabitats, including submerged leaf litter, branches and logs, as well as aquatic vegetation, marginal pits and cracks under and between riverbed stones (Magalhães, 2000; 2003).

According to Magalhães and Türkay (2008), Dilocarcinus H. Milne Edwards, 1853 comprises of Dilocarcinus pagei Stimpson, 1861, Dilocarcinus septemdentatus (Herbst, 1783) and Dilocarcinus truncatus Rodríguez, 1992. Dilocarcinus septemdentatus is found in Suriname, French Guiana and Brazil (Acre, Amazonas, Goiás, Maranhão, Pará and Maranhão), where it inhabits rivers and lakes in marginal areas with ravines as well as inside burrows, in shallow areas and in association with floating macrophyte roots (Magalhães, 2003; Magalhães and Türkay, 2008). The species is listed as "Least Concern" in the IUCN Red List of Threatened Species (Cumberlidge, 2008).

Studies of the juvenile stage of the Decapoda are important because all the characters used to identify species are exclusively based on adult morphology, which complicates their identification when they are juvenile. According to Martin et al. (1984), juvenile morphological studies may also help to clarify the phylogenetic relationships within Brachyura and facilitate their taxonomic identification. Considering the large number of brachyuran species in Brazil, there is little knowledge about the juvenile development of crabs. Juvenile development has only been described for three freshwater crabs: the trichodactylids Trichodactylus sp. by Müller (1892) and D. pagei by Vieira et al. (2013), and the pseudothelphusid Kingsleya ytupora Magalhães, 1986 by Wehrtmann et al. (2010). However, the latter authors described only the carapace of the first and second juvenile stages.

In this study we aim to provide the full description of the first juvenile stage of $D$. septemdentatus as well as to highlight the main differences in comparison with other Brazilian species from different habitats already described.

\section{Material and Methods}

One ovigerous female of $D$. septemdentatus was collected using a 3-mm mesh sieve on the banks of the Rio Preto creek (0059'59.2”S 4706'53.7”W) in Primavera, state of Pará, Brazil. The juveniles began hatching while still in the field and were preserved in $70 \%$ alcohol. 
The juveniles were counted and dissected in the laboratory. The appendages were fixed in a $96 \%$ alcohol and glycerin mixture (ratio of 1:1) and drawn in dorsal view using a Zeiss microscope equipped with a camera lucida. The dorsal and ventral views of the juveniles were photographed using a Leica M205A stereomicroscope equipped with a DFC420 camera, and the setae were counted for ten individuals. Measurements were made using an ocular micrometer. Descriptions are reported from the proximal to the distal segments, following Clark et al. (1998), and setae classified as simple or plumose.

Female and juveniles are deposited in the Museu Paraense Emilio Goeldi (MPEG) under catalog number MPEG 1174.

\section{Results}

A total of 101 juveniles hatched from the eggs. The female had a carapace width of $35 \mathrm{~mm}$. The juveniles had a mean carapace width of $1.62 \mathrm{~mm}$ (range: 1.43 $-1.75 \mathrm{~mm}$ ) and a mean carapace length of $1.57 \mathrm{~mm}$ (range: $1.23-1.71 \mathrm{~mm}$ ).

Similar to the adults, the carapace of the first juvenile stage of Dilocarcinus septemdentatus are wider than long, the abdomen extends beyond the first transverse suture of the thoracic sternum (fourth sternite), and the chelipeds have spines in the merus and carpus.

\section{Dilocarcinus septemdentatus (Herbst, 1783)}

Description of the first juvenile stage.

Carapace (Fig. 1A) slightly wider than long, subquadrangular, posterior margin wider than anterior one, convex in anteroposterior direction; front bilobed, slightly deflected. Dorsal region convex with simple and plumose setae sparsely; early differentiation of the gastric, cardiac, intestinal and branchial regions. Anterolateral margin with minute spine. Small red and brown spots over the entire dorsal region of carapace. Sternum (Fig. 1B) without setae.

Abdomen (Fig. 1C) attached to sternum, with six somites wider than long, extending beyond transverse suture of fourth sternite. Ventrally with four pairs of pleopodal buds from second to fifth somite.

Telson subtriangular, with small simple and plumose setae scattered on dorsal region.
Antennule (Fig. 2) with the basal segment welldeveloped with 8-11 simple and 12-15 plumose setae. Peduncle two-segmented, first segment smooth, second segment with 4 simple setae. Endopod (ventral flagellum) two-segmented, proximal segment with 1 subterminal simple seta, distal segment with 4 simple setae ( 2 subterminal and 2 terminal). Exopod (dorsal flagellum) 3-segmented; first segment smooth; second segment with 1 simple seta and 4 aesthetascs ending in a globose tip with a sharp point; third segment with 2 simple setae and 4 aesthetascs ending in a globose tip with a sharp point.

Antenna (Fig. 3) with peduncle three-segmented; first segment with 2 simple and 1 plumose setae; second segment with 3 simple setae; third segment with
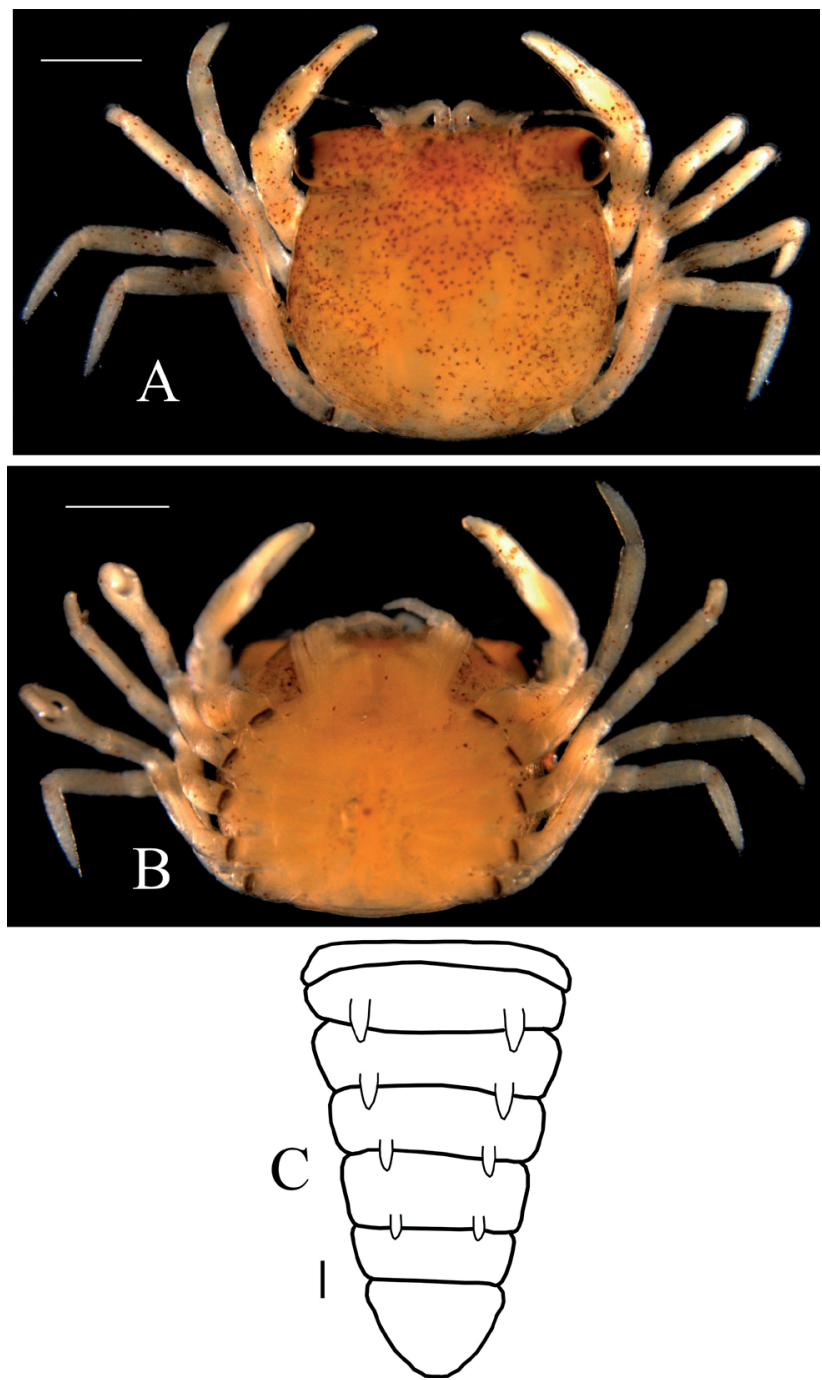

Figure 1. Dilocarcinus septemdentatus (Herbst, 1783), first juvenile stage. $A$, dorsal view; $B$, ventral view; $C$, ventral view of abdomen with pleopods. Scale bars: A, B = $1.0 \mathrm{~mm} ; C=0.1 \mathrm{~mm}$. 
1 simple seta. Antennal flagellum with 5 segments bearing $0,0,3,2,3$, simple setae, one of which extremely long.

Mandible (Fig. 4) with cutting blade and three segmented palp with $0,2,10$ plumose setae.

Maxillule (Fig. 5) with coxal endite with 10-13 plumose setae. Basal endite with 1-2 simple and 19-23 plumose setae. Endopod unsegmented, with 2 terminal plumose setae. Protopod with 2 long plumose setae.

Maxilla (Fig. 6) with coxal endite bilobed, proximal lobe without setae and distal lobe with 1 plumose seta. Basal endite bilobed with 3-4 simple and 8 plumose setae on the proximal lobe; distal lobe with 4-6 simple and 5 plumose setae. Endopod unsegmented with 1 plumose seta. Exopod (scaphognathite) with 82-90 marginal plumose setae and 8-12 simple setae on the dorsal surface.

First maxilliped (Fig. 7) with coxal endite with 14-17 plumose setae. Basal endite with 28-34 plumose setae. Endopod unsegmented with $0-1$ proximal plumose seta and 6-8 distal plumose setae. Exopod two-segmented with 6-13 plumose setae on the proximal segment and 4 long terminal plumose setae on the distal segment. Epipod with 8-12 proximal plumose setae, and 16-24 median and terminal plumose setae. No gills present.

Second maxilliped (Fig. 8) with protopod smooth. Endopod with five segments. Ischium with 1-2 simple and 5-9 plumose setae. Merus with 1-2 simple and 3-4 plumose setae. Carpus with 0-1 plumose seta. Propodus with 2 simple and 8-10 plumose setae. Dactylus with 10-14 plumose setae. Exopod twosegmented, proximal segment with $12-16$ plumose setae; distal segment with 4 long terminal plumose setae. Epipod with 9-14 plumose setae. Podobranch rudimentary.

Third maxilliped (Fig. 9) protopod with 6-9 simple and 22-31 plumose setae. Endopod five-segmented. Ischium with 12-17 simple and 12-11 plumose setae. Merus with 7-9 simple and 5-7 plumose setae. Carpus with 3-4 simple and 3-4 plumose setae. Propodus with 2-4 simple and 4-6 plumose setae. Dactylus with 5-7 plumose setae. Exopod two-segmented with 3-5 plumose setae on proximal segment and 4 long terminal plumose setae on distal segment. Epipod with 24-34 plumose setae. Arthrobranch rudimentary.

Chelipeds (Fig. 1A, B) symmetrical, covered with simple and plumose setae. Presence of small red and

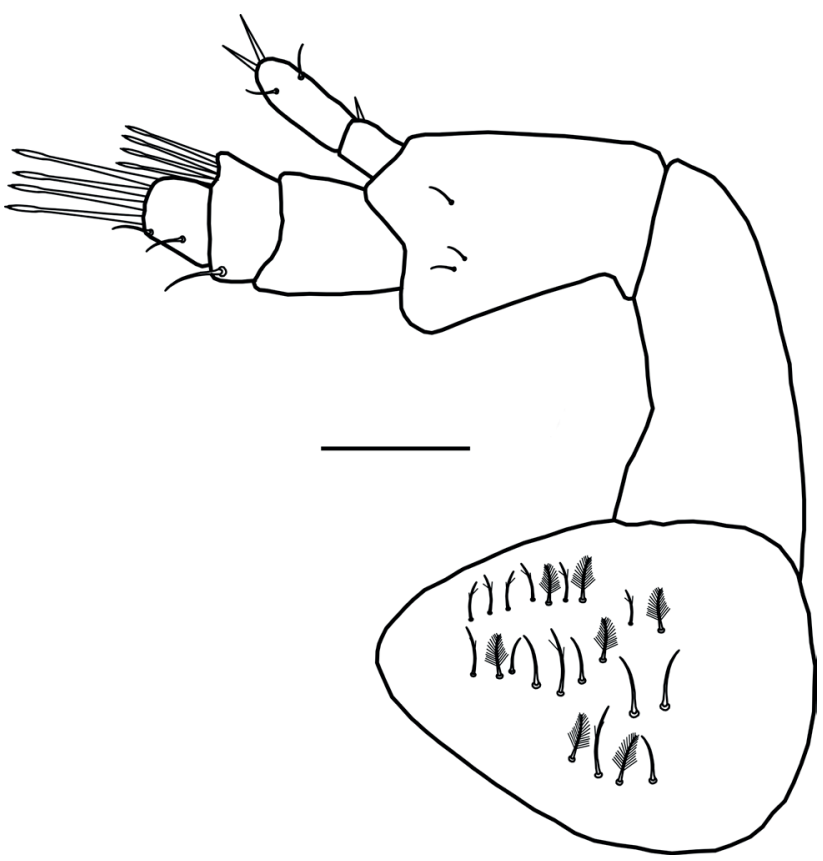

Figure 2. Dilocarcinus septemdentatus (Herbst, 1783). Lateral view of right antennule. Scale bar $=0.1 \mathrm{~mm}$.

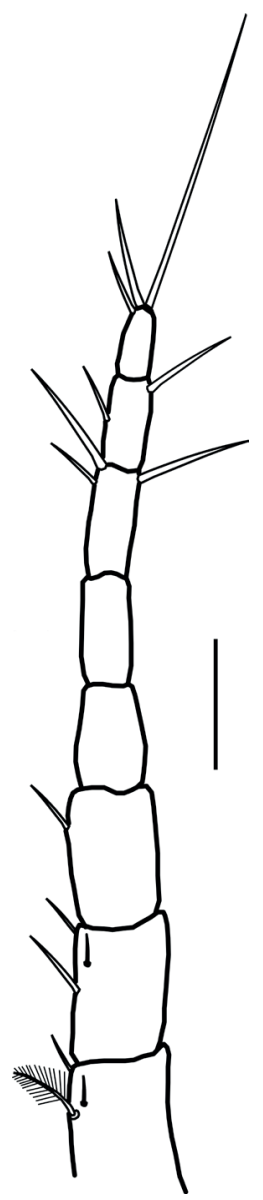

Figure 3. Dilocarcinus septemdentatus (Herbst, 1783). Dorsal view of right antenna. Scale bar $=0.1 \mathrm{~mm}$. 


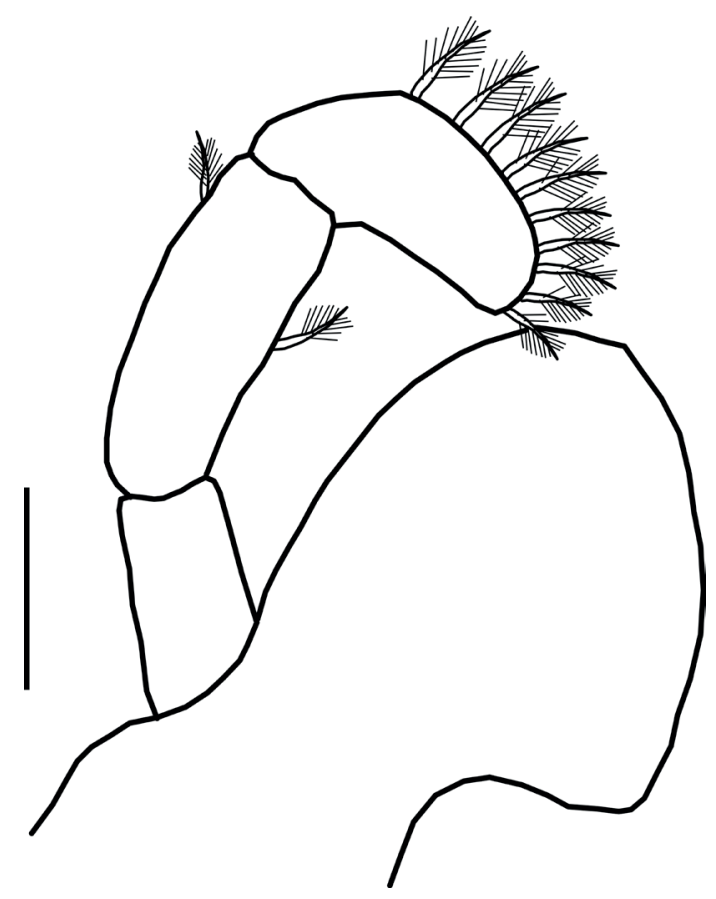

Figure 4. Dilocarcinus septemdentatus (Herbst, 1783). Dorsal view of left mandible. Scale bar $=0.1 \mathrm{~mm}$.

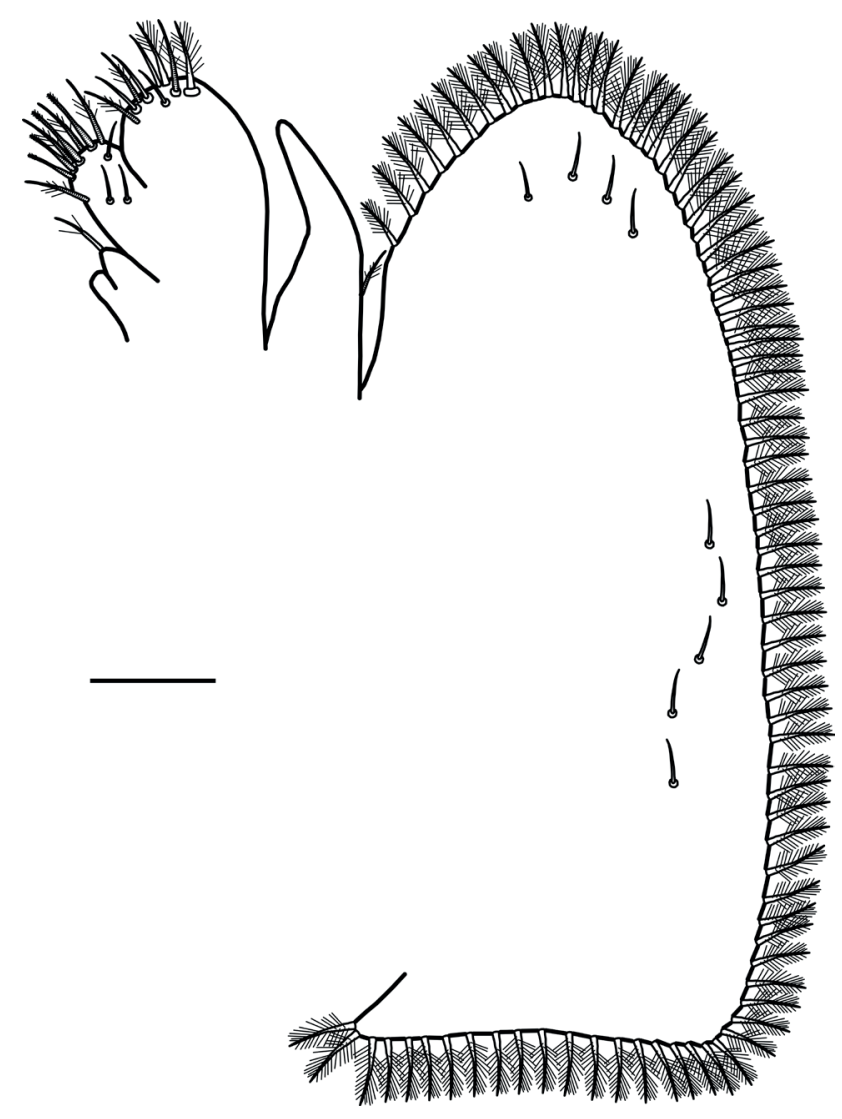

Figure 6. Dilocarcinus septemdentatus (Herbst, 1783). Dorsal view of right maxilla. Scale bar $=0.1 \mathrm{~mm}$.

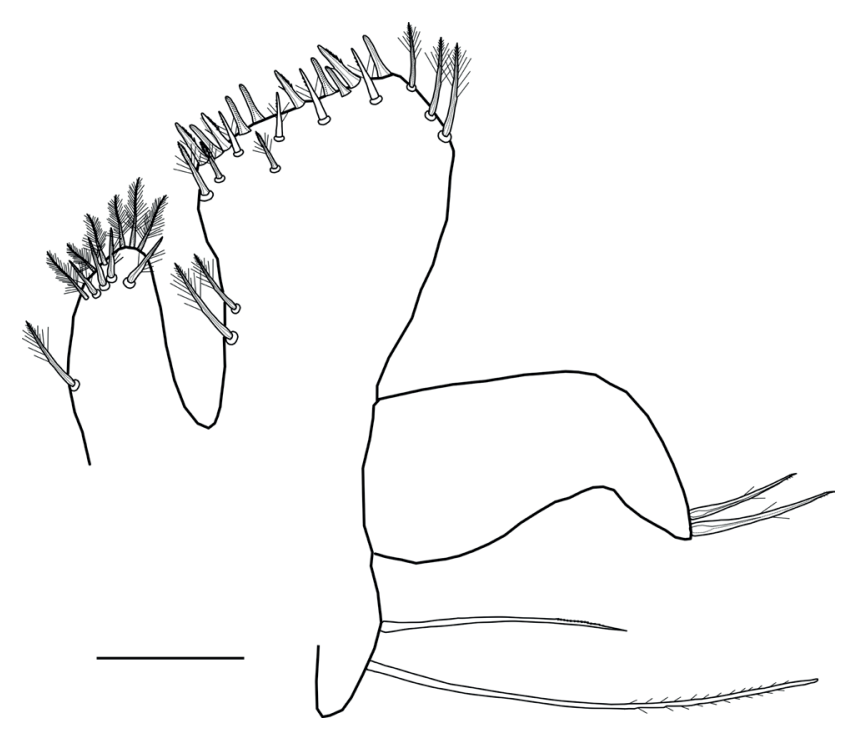

Figure 5. Dilocarcinus septemdentatus (Herbst, 1783). Dorsal view of right maxillule. Scale bar $=0.1 \mathrm{~mm}$.

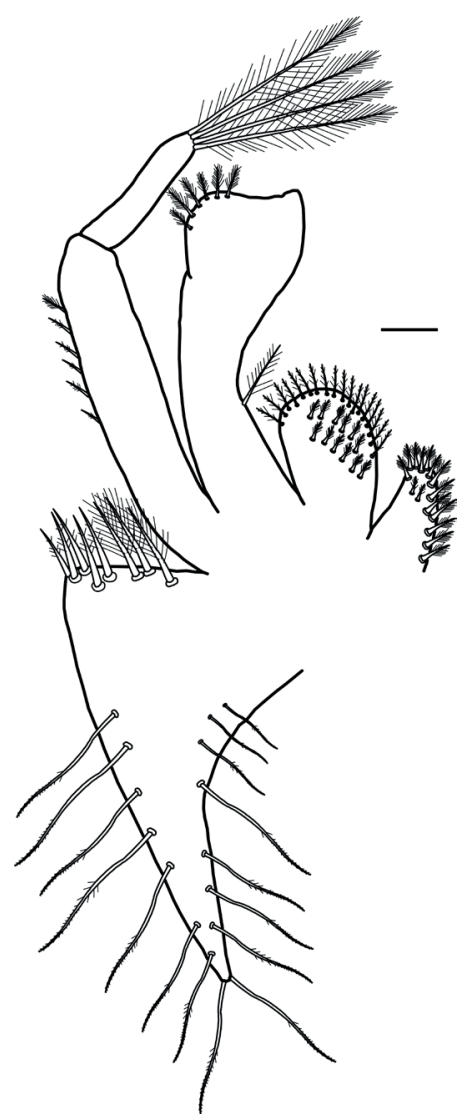

Figure 7. Dilocarcinus septemdentatus (Herbst, 1783). Dorsal view of left first maxilliped. Scale bar $=0.1 \mathrm{~mm}$. 


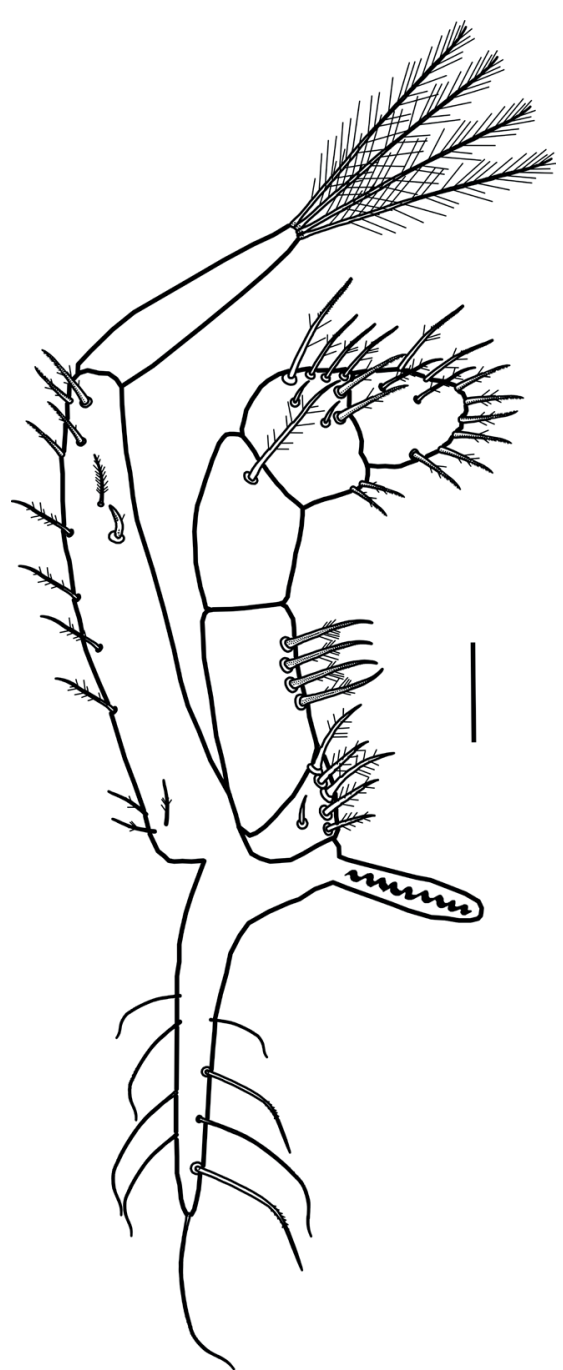

Figure 8. Dilocarcinus septemdentatus (Herbst, 1783). Dorsal view of left second maxilliped. Scale bar $=0.1 \mathrm{~mm}$.

brown dorsal spots on all chelipeds segments. Ischium with conspicuous dark pigmentation in ring format. Merus with prominent spine on anterolateral region. Carpus with distal spine on dorsolateral inner portion, near articulation with propodus.

Pereopods 2-5 (Fig. 1A, B) similar, with simple and plumose setae. Presence of small red and brown dorsal spots along pereopods. Ischium of all pereopods with conspicuous dark pigmentation in ring format.

\section{Discussion}

Direct development in Decapoda results from secondary embryogenesis of the ancestral larval stages (zoea and megalopa), with these phases occurring inside the egg (Felder et al., 1985). The main morphological differences between adults and

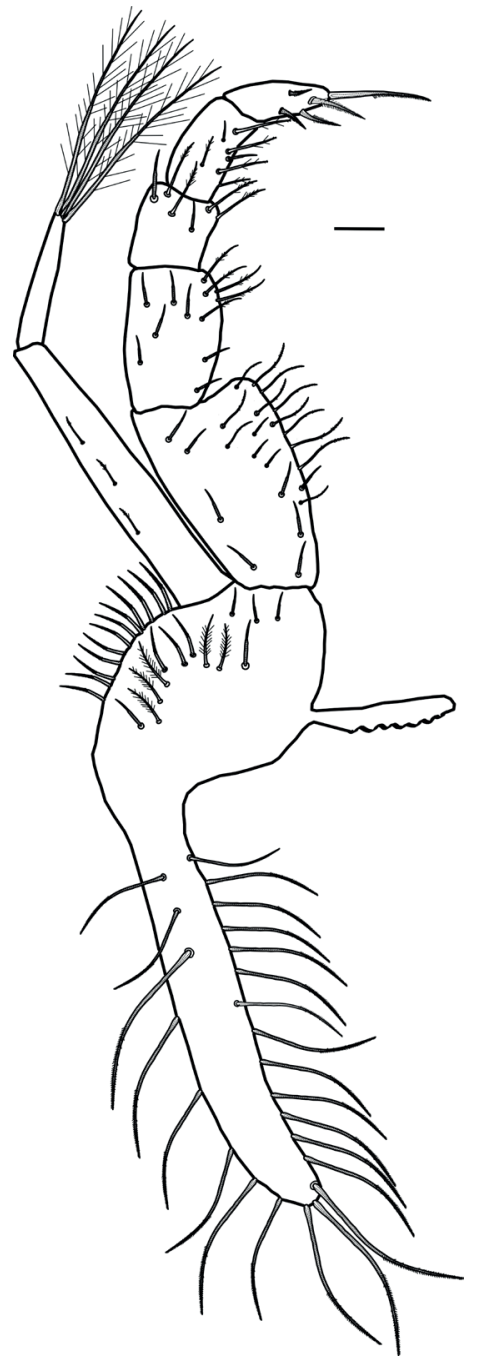

Figure 9. Dilocarcinus septemdentatus (Herbst, 1783). Dorsal view of left third maxilliped. Scale bar $=0.1 \mathrm{~mm}$.

juveniles of D. septemdentatus are: adults have 6-7 acute teeth on the anterolateral margin of the carapace whereas this margin is smooth in juveniles; adults have abdominal somites III-VI fused whereas they are free in juveniles; and the presence of four pairs of rudimentary pleopods on abdominal somites II-V in the juveniles (adult males have only the first and second pairs modified as gonopods, and adult females have all the four pairs of pleopods). In none of the juvenile specimens analyzed, it was possible to define the sex because there is no conspicuous modification in the pleopods. In D. pagei the sex differentiation begins at the second juvenile stage (Vieira et al., 2013), likely the same in D. septemdentatus.

The juveniles of D. septemdentatus (present study) and D. pagei (Vieira et al., 2013) are very similar 
morphologically and can only be differentiated through a combination of characters. D. septemdentatus has an antenna consisting of 8 segments and 3 setae on the sixth segment; the mandibular palp is 3-segmented; the basal endite of the maxillule has 20-24 setae; the basal endite of the first maxilliped has 28-34 setae; the exopod flagellum of the second maxilliped has 1 segment; and the protopodite of the third maxilliped has $28-40$ setae. For the same characteristics, D. pagei has 8 segments on the antenna and the sixth segment has 4 setae; the mandibular palp is 2 -segmented; the basal endite of the maxillule has 25-28 setae; the basal endite of the first maxilliped has 33-37 setae; the exopodal flagellum of the second maxilliped has 2 segments; and the protopodite of the third maxilliped has 41 setae (Vieira et al., 2013). In general, D. septemdentatus has fewer setae than D. pagei.

Juveniles of Trichodactylus sp. (Trichodactylinae) described by Müller (1892) differ from $D$. septemdentatus and D. pagei (Dilocarcininae) mainly because the exopod of the antennule consists of 2 segments instead 3; the antenna consists of 9 segments instead of 8; and the exopodal flagella of the first and third maxillipeds have 2 segments instead of 1 . Other variations among the Trichodactylidae species that had their first juvenile stage described are outlined in Tab. 1.

As Rodríguez (1992), Sternberg and Cumberlidge (2003) and Daniels et al. (2006) suggested that
Trichodactyloidea might have a marine origin and affinities with the Portunoidea, we performed a comparison with the first juvenile stage of Callinectes sapidus Rathbun, 1896 (see Barutot et al., 2001), Callinectes ornatus Ordway, 1863 (see Bolla Junior et al., 2008), D. pagei, D. septemdentatus, and Trichodactylus sp. (Tab. 2). Only the number of segments in the endopodite of the antennule is the same across the five species. While the species of Callinectes Stimpson, 1860 have 7 segments in the exopod of the antennule and the antenna have 10 or 11 segments, Dilocarcinus and Trichodactylus species have, at most, 3 segments in the exopod of the antennule, and the antenna has 8 or 9 segments. There are also variations in the number, size and shape of the aesthetascs and setae of the cephalic and thoracic appendages, with Dilocarcinus and Trichodactylus having a lower number. These variations might be adaptations to the freshwater environment in order to reduce the area of contact with the external environment, which is a key factor for maintaining osmotic balance. According to Lockwood (1962), marine species tend to be characterized by a high surface permeability to ions and water to sustain the blood concentration and, in general, freshwater species have a less permeable area than estuarine species. With the reduction of body surface, freshwater can promote further restriction of the permeability favoring the process of osmotic regulation (Lockwood, 1962).

Table 1. Morphological characters that allow the differentiation and identification of the first juvenile stages of Dilocarcinus septemdentatus (Herbst, 1848), Dilocarcinus pagei Stimpson, 1871 and Trichodactylus sp.

\begin{tabular}{lccc}
\hline & D. septemdentatus & D. pagei & Trichodatylus sp. \\
\hline Reference & Present study & Vieira et al. (2013) & Müller (1892) \\
\hline Antennule & + & + & - \\
Articles on exopod & 3 & 3 & 2 \\
Aesthetascs on exopod & $0+4+4$ & $0+4+3(4)$ & $3+3$ \\
$\begin{array}{l}\text { Antenna } \\
\text { Number of article }\end{array}$ & $3+5$ & $3+5$ & $4+5$ \\
$\begin{array}{l}\text { Mandible } \\
\text { Articles on palp }\end{array}$ & & 2 & 3 \\
$\begin{array}{l}\text { Maxillule } \\
\text { Articles on endopod } \\
\text { First maxilliped }\end{array}$ & 3 & 1 & 2 \\
$\begin{array}{l}\text { Articles on flagellum of exopod } \\
\text { Second maxilliped } \\
\text { Articles on flagellum of exopod }\end{array}$ & 1 & 1 & 2 \\
$\begin{array}{l}\text { Third maxilliped } \\
\text { Articles on flagellum of exopod }\end{array}$ & 1 & 2 & 2 \\
\hline
\end{tabular}


Table 2. Diagnostic characters that allow differentiation of the first juvenile stages of Brachyura species that occur in Brazilian waters for which the juvenile development is known.

\begin{tabular}{|c|c|c|c|c|c|c|c|}
\hline & Reference & $\begin{array}{l}\text { Article on } \\
\text { endopod of } \\
\text { antennule }\end{array}$ & $\begin{array}{l}\text { Article on } \\
\text { exopod of } \\
\text { antennule }\end{array}$ & $\begin{array}{l}\text { Number of } \\
\text { aesthetascs }\end{array}$ & $\begin{array}{l}\text { Article on } \\
\text { antenna }\end{array}$ & $\begin{array}{c}\text { Article on palp } \\
\text { of mandible }\end{array}$ & $\begin{array}{l}\text { Article on } \\
\text { Endopod of } \\
\text { maxillule }\end{array}$ \\
\hline \multicolumn{8}{|l|}{ Trichodactylidae } \\
\hline Dilocarcinus septemdentatus & Present study & 2 & 3 & 8 & $3+5$ & 3 & 1 \\
\hline Dilocarcinus pagei & Vieira et al. (2013) & 2 & 3 & $7-8$ & $3+5$ & 2 & 1 \\
\hline Trichodactylus sp. & Müller (1892) & 2 & 2 & 6 & $4+5$ & 3 & 2 \\
\hline \multicolumn{8}{|l|}{ Aethridae } \\
\hline Hepatus pudibundus & Hebling and Rieger (2003) & 2 & 8 & 31 & $3+7$ & 2 & 1 \\
\hline \multicolumn{8}{|l|}{ Inachidae } \\
\hline Stenorhynchus seticornis & Yang (1976) & 2 & 4 & 13 & $3+5$ & 2 & 2 \\
\hline \multicolumn{8}{|l|}{ Inachoididae } \\
\hline Pyromaia tuberculata & Luppi and Spivak (2003) & 3 & 4 & 14 & $3+5$ & 2 & 2 \\
\hline \multicolumn{8}{|l|}{ Mithracidae } \\
\hline Mithraculus sculptus & Rhyne et al. (2006) & 2 & 4 & 13 a 16 & $3+6$ & 2 & 1 \\
\hline \multicolumn{8}{|l|}{ Parthenopidae } \\
\hline Parthenope serrata & Yang (1971) & 2 & 5 & $?$ & $3+7$ & 2 & 2 \\
\hline \multicolumn{8}{|l|}{ Portunidae } \\
\hline Callinectes ornatus & Bolla Junior et al. (2008) & 2 & 7 & 32 & $3+10(11)$ & 3 & 2 \\
\hline Callinectes sapidus & Barutot et al. (2001) & 2 & 7 & 15 a 18 & $3+8$ & 3 & 2 \\
\hline \multicolumn{8}{|l|}{ Panopeidae } \\
\hline Eriphia gonagra & Fransozo and Negreiros-Fransozo (1987) & 3 & 6 & $26-28$ & $4+8$ & 2 & 2 \\
\hline Eurypanopeus abbreviatus & Fransozo and Negreiros-Fransozo (1987) & 2 & 3 & 10 & $4+7$ & 3 & 1 \\
\hline Eurytium limosum & Guimarães and Negreiros-Fransozo (2005) & 2 & 5 & 15 & $3+7$ & 2 & 1 \\
\hline Menippe nodifrons & Fransozo et al. (1988) & 2 & 8 & 36 & $3+9$ & 2 & 2 \\
\hline Panopeus herbstii & Hebling et al. (1982) & 2 & 4 & 14 a 15 & $3+7$ & 2 & 2 \\
\hline \multicolumn{8}{|l|}{ Grapsidae } \\
\hline Pachygrapsus transversus & Flores et al. (1998) & 3 & 6 & 18 & $3+8$ & 3 & 2 \\
\hline \multicolumn{8}{|l|}{ Sesarmidae } \\
\hline Armases rubripes & Diaz and Ewald (1968) & Absent & $?$ & 4 & $3+5$ & 2 & 2 \\
\hline Metopaulias depressus & González-Gordillo et al. (2010) & Absent & 2 & 4 & $2+6$ & 2 & 1 \\
\hline Sesarma rectum & Fransozo $(1986 / 87)$ & Absent & 2 & 3 & $3+5$ & 2 & 2 \\
\hline \multicolumn{8}{|l|}{ Varunidae } \\
\hline Cyrtograpsus angulatus & Rieger and Beltrão (2000) & 2 & 4 & $11-16$ & $3+7(6)$ & 3 & 2 \\
\hline Neohelice granulata & Rieger and Nakagawa (1995) & 2 & 4 & 12 & $3+7$ & 2 & 2 \\
\hline \multicolumn{8}{|l|}{ Ocypodidae } \\
\hline Uca burgersi & Vieira et al. (2010) & 1 & 3 & $9-11$ & $3+6$ & 3 & 2 \\
\hline
\end{tabular}


In D. septemdentatus, D. pagei and some Grapsoidea species from estuarine and semiterrestrial habitats the antenna has one simple and extremely long seta located on the last and penultimate segments (see Diaz and Ewald, 1968; Fransozo, 1986/87; Rieger and Nakagawa, 1995; Flores et al., 1998; Rieger and Beltrão, 2000), this simple seta is presumably sensorial (Bauer and Caskey, 2006). Others types of setae have mechanical functions in Decapoda. Plumose, serrate and plumodenticulate setae are adapted for particle retention and the promotion of water flow, scrape and brush other setae and surfaces or to release food from substrates (Thomas, 1970; Farmer, 1974; Felgenhauer and Abele, 1983; Alexander and Hindley, 1985; Martin and Felgenhauer, 1986; Watling, 1989; Garm, 2004).

Aesthetascs are structures found on the terminal end of the outer flagellum of antennules in decapods; they have a chemoreceptor function and are involved in the detection of sex pheromones (Meusy and Payen, 1988). A striking characteristic of decapods is the variation in the number and morphology of aesthetascs that occur among marine, estuarine, freshwater and semiterrestrial species (Tab. 2). Marine species with juvenile development already described belonging to Aethridae Dana, 1851, Inachidae MacLeay, 1838, Inachoididae Dana, 1851, Mithracidae MacLeay, 1838, Parthenopidae MacLeay, 1838, Portunidae Rafinesque, 1815 (Callinectes ornatus) and Panopeidae Ortmann, 1893 have 13-32 long aesthetascs (Yang, 1971; 1976; Hebling et al., 1982; Fransozo and NegreirosFransozo, 1987; Fransozo et al., 1988; Hebling and Rieger, 2003; Luppi and Spivak, 2003; Rhyne et al., 2006; Bolla Junior et al., 2008). Meanwhile, estuarine species, including Portunidae (C. sapidus), Grapsidae MacLeay, 1838, Varunidae H. Milne Edwards, 1853, Panopeidae [Eurypanopeus abbreviatus (Stimpson, 1860) and Eurytium limosum (Say, 1818)] and Ocypodidae Rafinesque, 1815 have $10-18$ aesthetascs usually shorter than those of marine species (Tab. 2) (Fransozo and Negreiros-Fransozo, 1987; Rieger and Nakagawa, 1995; Flores et al., 1998; Rieger and Beltrão, 2000; Barutot et al., 2001; Guimarães and NegreirosFransozo, 2005; Vieira et al., 2010).

Compared to marine species, the number of aesthetascs is lower in juveniles of Trichodactylidae (6 to 8) and larger than in juveniles of semiterrestrial species of Sesarmidae Dana, 1851, with only up to 4 aesthetascs (see Müller, 1892; Diaz and Ewald, 1968; Fransozo 1986/87; González-Gordillo et al., 2010; Vieira et al., 2013). According to Shenoy et al. (1993), the aesthetascs of marine species present thin cuticles that are pointed or uniformly rounded and, in the estuarine species, the aesthetacs are short and robust. The morphological changes in the aesthetascs from marine to semiterrestrial species occur as reduction of number and size a well ass thickening trends. These modifications likely facilitate the conservation of water and sodium ions and have the function to prevent against the wear to which aesthetascs of freshwater and semiterrestrial species are subjected (Edmondson, 1929; Shenoy et al., 1993).

\section{ACKNOWLEDGEMENTS}

The authors thank Dr. Inocêncio Gorayeb, of the Entomology Laboratory of the Museu Paraense Emílio Goeldi (MPEG), for allowing the use of the microscope, and Dr. Alexandre Bragio Bonaldo and Dra. Yulie Shimano of the MPEG Arachnology Laboratory, for their permission and assistance in the use of the stereomicroscope. Rony R. R. Vieira was a recipient of a scientific grant from Museu Paraense Emílio Goeldi (Programa Capacitação Institucional - CNPq 170093/2016-6).

\section{References}

Alexander, C.G.H. and Hindley, J.P.R. 1985. The mechanism of food ingestion by the banana prawn, Penaeus merguiensis. Marine Behaviour and Physiology, 12: 33-46.

Barutot, R.A.; Vieira, R.R.R. and Rieger, P.J. 2001. Desenvolvimento juvenil de Callinectes sapidus Rathbun, 1896 (Crustacea: Decapoda: Portunidae), em laboratório, a partir de megalopas coletada no plâncton. Comunicações do Museu de Ciências e Tecnologia da PUCRS, Série Zoologia, 14: 23-42.

Bauer, R.T. and Caskey, J.L. 2006. Flagellar setae of the second antennae in decapod shrimps: sexual dimorphism and possible role in detection of contact sex pheromones. Invertebrate Reproduction and Development, 49: 51-60.

Bolla Júnior, E.A.; Negreiros-Fransozo, M.L. and Fransozo, A. 2008. Juvenile development of Callinectes ornatus Ordway, 1863 (Crustacea: Decapoda: Portunidae), from megalopae obtained in the neuston. Zootaxa, 1788: 1-20.

Bott, R. 1970. Die Süßwasserkrabben von Europa, Asien, Australien und ihre Stammesgeschichte. Eine Revision der Potamoidea und der Parathelphusoidea (Crustacea, Decapoda). Abhandlungen der Senckenbergischen Naturforschenden Gesellschaft, 526: 1-338. 
Clark, P.F.; Calazans, D.K and Pohle, G.W. 1998. Accuracy and standardization of brachyuran larval descriptions. Invertebrate Reproduction and Development, 33: 127-144.

Cumberlidge, N. 1999. The freshwater crabs of West Africa. Family Potamonautidae. p. 1-382. In: P. Rondeau (ed), Faune et Flore Tropicales. Vol. 35. Paris, Institut de Recherche pour le Développment.

Cumberlidge, N. 2008. Dilocarcinus septemdentatus. The IUCN Red List of Threatened Species 2008:e.T134191A3917116. doi: 10.2305/IUCN.UK.2008.RLTS.T134191A3917116.en

Cumberlidge, N. and Ng, P.K.L. 2009. Systematics, evolution, and biogeography of freshwater crabs. p. 491-508. In: J.W. Martin; K.A. Crandall and D.L. Felder (eds), Decapod Crustacean Phylogenetics. Crustacean Issues, 18. Boca Raton, London, New York: CRC Press, Taylor and Francis Group.

Daniels, S.R.; Cumberlidge, N.; Pérez-Losada, M.; Marijnissen, S.A.E. and Crandall, K.E. 2006. Evolution of Afrotropical freshwater crab lineages obscured by morphological convergence. Molecular Phylogenetics and Evolution, 40: 227-235.

De Grave, S.; Pentcheff, N.D.; Ahyong, S.T.; Chan, T.-Y.; Crandall, K.A.; Dworschak, P.C.; Felder, D.L.; Feldmann, R.M.; Fransen, C.H.J.M.; Goulding, L.Y.D.; Lemaitre, R.; Low, M.E.Y.; Martin, J.W.; Ng, P.K.L.; Schweitzer, C.E.; Tan, S.H.; Tshudy, D. and Wetzer, R. 2009. A classification of living and fossil genera of decapod crustaceans. Raffles Bulletin of Zoology, 21: 1-109.

Diaz, H. and Ewald, J.J. 1968. A comparison of the larval development of Metasesarma rubripes (Rathbun) and Sesarma ricordi $\mathrm{H}$. Milne Edwards (Brachyura, Grapsidae) reared under similar laboratory conditions. Crustaceana, Supplement 2: 225-248.

Edmondson, C.H. 1929. Hawaiian Atyidae. Bulletin of the Bernice P. Bishop Museum, 66: 1-36.

Farmer, A.S. 1974. The functional morphology of the mouthparts and pereiopods of Nephrops norvegicus (L.) (Decapoda: Nephropidae). Journal of Natural History, 8: 121-142.

Felder, D.L.; Martin, J.W. and Goy, J.W. 1985. Patterns in early postlarval development of decapods. p. 163-225. In: A.M. Wenner (ed), Larval Growth. Crustacean Issues, 2. Rotterdam, Balkema Press.

Felgenhauer, B.E. and Abele, L.G. 1983. Ultrastructure and functional morphology of feeding and associated appendages in the tropical fresh-water shrimp Atya innocous (Herbst) with notes on its ecology. Journal of Crustacean Biology, 3: 336-363.

Flores, A.A.V.; Negreiros-Fransozo, M.L. and Fransozo, A. 1998. The megalopa and juvenile development of Pachygrapsus transversus (Gibbes, 1850) (Decapoda, Brachyura) compared with other grapsid crabs. Crustaceana, 71: 197-222.

Fransozo, A. 1986/87. Desenvolvimento dos estágios juvenis de Sesarma (Holometopus) rectum Randall, 1840 (Decapoda, Grapsidae) obtidos em laboratório. Naturalia, 11/12: 77-87.

Fransozo, A. and Negreiros-Fransozo, M.L. 1987. Morfologia dos primeiros estágios juvenis de Eriphia gonagra (Fabricius, 1781) e Eurypanopeus abbreviatus (Stimpson, 1860) (Crustacea, Decapoda, Xanthidae), obtidos em laboratório. Papéis Avulsos de Zoologia, São Paulo, 36: 257-277.

Fransozo, A.; Negreiros-Fransozo, M.L. and Hiyodo, C.M. 1988. Développement juvenile de Menippe nodifrons Stimpson, 1859 (Crustacea, Decapoda, Xanthidae) au laboratoire. Revue d'Hydrobiologie Tropicale, 21: 297-308.

Garm, A. 2004. Revising the definition of the crustacean seta and setal classification systems based on examinations of the mouthpart setae of seven species of decapods. Zoological Journal of the Linnean Society, 142: 233-252.

González-Gordillo, J.I.; Anger, K. and Schubart, C.D. 2010. Morphology of the larval and first juvenile stages of two Jamaican endemic crab species with abbreviated development, Sesarma windsor and Metopaulias depressus (Decapoda: Brachyura: Sesarmidae). Journal of Crustacean Biology, 30: 101-121.

Guimarães, F.J. and Negreiros-Fransozo, M.L. 2005. Juvenile development and growth patterns in the mud crab Eurytium limosum (Say, 1818) (Decapoda, Brachyura, Xanthidae) under laboratory conditions. Journal Natural History, 39: 2145-2161.

Hebling, N.J.; Fransozo, A. and Negreiros-Fransozo, M.L. 1982. Desenvolvimento dos primeiros estágios juvenis de Panopeus herbstii H. Milne-Edwards, 1834 (Crustacea, Decapoda, Xanthidae) criados em laboratório. Naturalia, São Paulo, 7: 177-188.

Hebling, N.J. and Rieger, P.J. 2003. Desenvolvimento juvenil de Hepatus pudibundus (Herbst) (Crustacea, Decapoda, Calappidae), em laboratório. Revista brasileira de Zoologia, 20: 531-539.

Herbst, J.F.W. 1783. Versuch einer Naturgeschichte der Krabben und Krebse, nebst einer systematischen Berschreibung ihrer werschiedenen Arten. p. 87-182. Berlin, Gottlieb August Lange, 1.

Latreille, P.A. 1802. Histoire naturelle, générale et particulière des Crustacés et des Insectes, v. 3. Paris, F. Dufart. 467pp.

Lockwood, A.P.M. 1962. The osmoregulation of Crustacea. Biological Reviews, 37: 257-303.

Luppi, T.A. and Spivak, E.D. 2003. Postembryonic development of Pyromaia tuberculata (Lockington, 1877): a review of larval and postlarval morphology. Scientia Marina, 67: 201-214.

MacLeay, W.S. 1838. On the brachyurous decapod Crustacea brought from the Cape by Dr. Smith p. 53-71. In: A. Smith (ed), Illustrations of the Annulosa of South Africa; being a portion of the objects of natural history chiefly collected during an expedition into the interior of South Africa, under the direction of Dr. Andrew Smith, in the years 1834, 1835. and 1836; fitted out by "The Cape of Good Hope Association for Exploring Central Africa”. London: Smith, Elder, and Co.

Magalhães, C. 1986. Revisão taxonômica dos caranguejos de água doce brasileiros da família Pseudothelphusidae (Crustacea, Decapoda). Amazoniana, 9: 609-636.

Magalhães, C. 2000. Diversity and abundance of decapod crustaceans in the Rio Negro basin, Pantanal, Mato Grosso 
do Sul Brazil. p. 56-62. In: B. Chernoff; L.E. Alonso; J.R. Montambault and R. Lourival (eds), A biological assessment of the aquatic ecossystems of the Pantanal, Mato Grosso do Sul, Brazil. Bulletin of Biological Assessment, 18. Washington, D.C., Conservation International.

Magalhães, C. 2003. Famílias Pseudothelphusidae e Trichodactylidae. p. 143-287. In: G.A.S. Melo (ed), Manual de identificação dos Crustacea Decapoda de água doce do Brasil. São Paulo, Loyola.

Magalhães, C. and Türkay, M. 2008. Taxonomy of the Neotropical freshwater crab family Trichodactylidae, IV. The genera Dilocarcinus and Poppiana (Crustacea, Decapoda, Trichodactylidae). Senckenbergiana biologica, 88: 185-215.

Martin, J.W. and Davis, G.E. 2001. An updated classification of the recent Crustacea. Contributions in Science, 39: 1-123.

Martin, J.W.; Felder, D.L. and Truesdale, F.M. 1984. A comparative study of morphology and ontogeny in juvenile stages of four western Atlantic xanthoid crabs (Crustacea: Decapoda: Brachyura). Philosophical Transactions of the Royal Society B: Biological Sciences, 303: 537-604.

Martin, J.W. and Felgenhauer, B.E. 1986. Grooming behaviour and the morphology of grooming appendages in the endemic South America crab genus Aegla (Decapoda, Anomura, Aeglidae). Journal of Zoology, Ser. A, 209: 213-224.

Meusy, J.J. and Payen, G.G. 1988. Female reproduction in Malacostraca Crustacea. Review. Zoological Science, 5: 217265.

Milne Edwards, H. 1853. Mémoire sur la famille des Ocypodiens. Annales des Sciences Naturelles, 20: 163-228.

Müller, F. 1892. Trichodactylus, siri de água doce, sem metamorphose. Archivos do Museu Nacional, Rio de Janeiro, 8: $125-135$.

Ng, P.N.; Guinot, D. and Davie, P.J.F. 2008. Systema Brachyurorum: Part I. An Annotated checklist of Extant Brachyuran crabs of the world. The Raffles Bulletin of Zoology, Supplement 17: $1-286$.

Ortmann, A.E. 1893. Die Decapoden-Krebse des Strassburger Museums, mit besonderer Berücksichtigung der von Herrn Dr. Döderlein bei Japan und bei den Liu-Kiu-Inseln gesammelten und zur Zeit im Strassburger Museum aufbewahrten Formen. VI Theil. Abtheilung: Brachyura (Brachyura genuina Boas), I. Unterabtheilung: Majoidea und Cancroidea, 1: Section Portuninea. Zoologische Jahrbücher. Abteilung für Systematik, Geographie und Biologie der Thiere, 7: 23-88.

Pretzmann, G. (1978) Neue Süsswasserkrabben aus den Anden. Sitzungsberichte der Mathematisch-Naturwissenschaftlichen Klasse der Österreichischen Akademie der Wissenschaften, Wien 187: $163-170$.

Rafinesque, C. S. 1815. Analyse de la Nature, ou Tableau de l'Univers et des Corps Organisés. Palermo, L'Imprimerie de Jean Barravecchia. 224p.

Rhyne, A.L.; Fujita, Y. and Calado, R. 2006. Larval development and first crab of Mithraculus sculptus (Decapoda: Brachyura:
Majoidea: Mitrhracidae) described from laboratory-reared material. Journal of the Marine Biological Association of the United Kingdom, 86: 1133-1147.

Rieger, P.J. and Nakagawa, C. 1995. Desenvolvimento juvenil de Chasmagnathus granulata Dana, 1851 (Crustacea, Decapoda, Grapsidae), em laboratório. Nauplius, 3: 59-74.

Rieger, P.J. and Beltrão, R. 2000. Desenvolvimento juvenil de Cyrtograpsus angulatus Dana (Crustacea, Decapoda, Grapsidae), em laboratório. Revista brasileira de Zoologia, 17: 405-420.

Rodríguez, G. 1992. The freshwater crabs of America. Family Trichodactylidae and Supplement to the Family Pseudothelphusidae. Faune Tropicale, 31. Paris, ORSTOM. $189 \mathrm{p}$.

Say, T. 1818. An account of Crustacea of the United States. Journal of the Academy of Natural Sciences of Philadelphia, 2: 235-253; 313-319; 374-401; 423-444; 445-458.

Shenoy, S.; Jalihal, D.R. and Sankolli, K.N. 1993. Ecological diversity with reference to aesthetascs in freshwater prawns. Crustaceana, 65: 300-308.

Sternberg, R. von and Cumberlidge, N. 2003. Autapomorphies of the endophragmal system in trichodactylid freshwater crabs. Journal of Morphology, 256: 23-28.

Sternberg, R. von; Cumberlidge, N. and Rodriguez, G. 1999. On the marine sister groups of the freshwater crabs (Crustacea: Decapoda: Brachyura). Journal of Zoological Systematics and Evolutionary Research, 37: 19-38.

Števčić, Z. 2005. The reclassification of brachyuran crabs (Crustacea: Decapoda: Brachyura). Fauna Croatica 14: 1-159.

Stimpson, W. M. 1861. Notes on certain decapod Crustacea. Proceedings of the Academy of Natural Science of Philadelphia, 13: 372-375.

Thomas, W.J. 1970. The setae of Austropotamobius pallipes (Crustacea: Astacidae). Journal of Zoology, 160: 91-142.

Vieira, R.R.R.; Pinho, G.L.L. and Rieger, P.J. 2010. Juvenile development of Uca (Minuca) burgersi Holthuis, 1967 (Crustacea, Brachyura, Ocypodidae) in the laboratory. Atlântica, 32: 59-70.

Vieira, R.R.R.; Rieger, P.J.; Cichowski, V. and Pinheiro, M.A.A. 2013. Juvenile development of Dilocarcinus pagei Stimpson, 1861 (Brachyura, Trichodactylidae) reared in the laboratory, with emphasis on setae morphology. Crustaceana, 86: 16441663.

Watling, L. 1989. A classification system for crustacean setae based on the homology concept. p. 15-26. In: B.E. Felgenhauer; L. Watling and A.B. Thistle (eds), Functional morphology of feeding and grooming in Crustacea. Crustacean Issues, 6 . Rotterdam, A. A. Balkema.

Wehrtmann, I. S.; Magalhães, C.; Hernáez, P. and Mantelatto, F. L. 2010. Offspring production in three freshwater crab species (Brachyura: Pseudothelphusidae) from the Amazon region and Central America. Zoologia, 27: 965-972.

Williamson, D.I. 1969. Names of larvae in the Decapoda and Euphausiacea. Crustaceana, 16: 210-213. 
Yang, W.T. 1971. The larval and postlarval development of Parthenope serrate reared in the laboratory and the systematic position of the Parthenopinae (Crustacea, Brachyura). The Biological Bulletin, 40: 166-189.
Yang, W.T. 1976. Studies on the western Atlantic arrow crab genus Stenorhynchus (Decapoda, Brachyura, Majidae). I. Larval characters of two species and comparison with other larvae on Inachinae. Crustaceana, 31: 157-177. 